\title{
TUẦ HOÀN FONTAN SAU NỬA THẾ KỶ
}

\section{Lê Minh Khôi ${ }^{*}$, Nguyễn Hoàng Định*, Truoong Quang Bình*}

\section{TÓM TÁT}

Tim một thất chức năng đã được mô tả từ cuối thế kỷ XVII. Đây là một nhóm bệnh tim bẩm sinh đặc biệt cả về sự phức tạp, tính đa dạng về tổn thương giải phẫu cũng như những biến đổi về huyết động và sinh lý tim mạch. Phẫu thuật Fontan được thực hiện lần đầu tiên vào năm 1968, cách nay đúng nửa thế kỷ, có thể được xem như một cuộc cách mạng trong phẫu thuật tim mạch. Phẫu thuật Fontan cùng với những cải tiến về kỹ thuật, can thiệp, điều trị nội khoa cũng như những kiến thức mới về sinh lý tuần hoàn Fontan đã cải thiện một cách rõ rệt tiên lượng của bệnh nhân mắc bệnh tim một thất chức năng, kéo dài tuổi thọ, giảm biến chứng, nâng cao chất lượng cuộc sống. Tuy vậy BN Fontan vẫn được xem là nhóm bệnh suy tim còn bù và có thể chuyển sang mất bù vào bất cứ lúc nào. Những biến chứng của tuần hoàn Fontan vẫn luôn đặt ra những thách thức không nhỏ cho thầy thuốc lâm sàng. Bài viết này sẽ điểm qua những cột mốc lịch sử quan trọng trong phẫu thuật và can thiệp tuần hoàn Fontan, sơ bộ nêu lên những thể giải phẫu, sinh lý tim một thất, chiến lược tiếp cận bệnh tim một thất chức năng, những biến chứng của tuần hoàn Fontan và những triển vọng điều trị trong tương lai.

Từ khoá: tuần hoàn Fontan, tim một thất, tim bẩm sinh, phẫu thuật tim

\section{SUMMARY}

Functional single ventricle was described at the end of the $17^{\text {th }}$ century. This is a special group of congenital heart disease characterized by the high complexity and diversity of anatomic lesions as well as changes in hemodynamics and cardiovascular physiology.
Fontan procedure was succesfully carried out for the first time in 1968, half a century ago, which could be considered as a revolutionary leap in the field of cardiovascular surgery. The Fontan procedure, in parallel with innovation and refinement in surgical techniques, interventional cardiology, medical management as well as breakthrough scientific knowledge in Fontan circulation, has signigficantly improved the outcomes of patients suffering from functional single ventricle increasing lifespan, reducing complications, enhancing quality of life. Fontan patients are, however, still seen as a group of patients with compensated heart failure and constantly are at risk of decompensation at any time. Complications associated with Fontan circulation always put clinicians at tremendous challenges. This review is conceived to briefly outline the important Bệnh viện Nội tiết Trung ương historical milestones in surgery and intervention in patients with Fontan circulation, to describe the anatomic lesions and physiology of functional single ventricle, clinical approach to the management of patients with functional single ventricle, complications related to Fontan circulation and future perspectives.

Keywords: Fontan circulation, single ventricle, congenital heart disease, cardiac surgery.

\section{GIỚI THIỆU}

Ngay từ năm 1699, Chemineau đã mô tả

*Trung tâm Tim mach, BV Đại học Y Dược TP Hồ Chí Minh Nguoòi chịu trách nhiệm khoa học: PGS.TS. Lê Minh Khôi

Ngày nhận bài: 01/04/2018 - Ngày Cho Phép Đăng: 10/04/2018

Phản Biện Khoa học: PGS.TS. Đặng Ngọc Hùng GS.TS. Lê Ngoc Thành 
một trái tim có hai buồng nhĩ nhưng chỉ có một thất. Từ đó, tim một thất đã ám ảnh cộng đồng y khoa suốt nhiều thế kỷ. Được đặc trưng bởi tính phức tạp cao độ cũng như phổ tổn thương giải phẫu và biến loạn sinh lý tim mạch rất đa dạng, tim một thất đã gây nên những tranh cãi gay gắt về phôi thai học và danh pháp, thách thức những hiểu biết của chúng ta trong lĩnh vực sinh lý và huyết động tim mạch nhưng đồng thời cũng truyền cảm hứng cho những kỹ thuật phẫu thuật và can thiệp sáng tạo nhất trong lịch sử y học [22].

Tim một thất chức năng là một nhóm bệnh tim bẩm sinh trong đó chỉ có một buồng thất có hoạt động chức năng. Trong tim một thất chức năng chưa được sửa chữa, máu tĩnh mạch $(\mathrm{TM})$ hệ thống và máu TM phổi được trộn lẫn nhau trong một buồng thất chính và sau đó được bơm đồng thời vào tuần hoàn hệ thống và tuần hoàn phổi. Hậu quả là buồng thất độc nhất tăng tải và bão hoà ôxy máu ngoại biên thấp gây nên biểu hiện tím. Do không thể phẫu thuật theo hướng hai thất chức năng nên những bệnh nhân $(\mathrm{BN})$ này sẽ được điều trị theo hướng phẫu thuật một thất, nghĩa là thiết lập tuần hoàn Fontan. Trong tuần hoàn Fontan, toàn bộ lượng máu TM hệ thống sẽ được dẫn trực tiếp về động mạch (ĐM) phổi theo chênh áp thuỷ tĩnh mà không hề được bơm bởi một buồng thất nào. Trong tim sẽ không có sự hoà trộn giữa máu TM hệ thống và máu TM phổi. Nhờ đó $\mathrm{BN}$ đạt được độ bão hoà ôxy máu $\mathrm{MM}$ hệ thống trong giới hạn bình thường [17].

Phẫu thuật Fontan được thực hiện lần đầu tiên vào năm 1968, cách đây đúng nửa thế kỷ, để điều trị $\mathrm{BN}$ mắc bệnh tim bẩm sinh teo van ba lá [9]. Phương thức phẫu thuật này sau đó được mở rộng áp dụng trên một phổ rộng các bất thường bẩm sinh có chung một đặc trưng là những $\mathrm{BN}$ này chỉ có một buồng thất chức năng và việc sửa chữa theo hướng hai thất là không thể thực hiện được.

Tuần hoàn Fontan là một minh hoạ sống động về tầm quan trọng của việc đánh giá theo dõi lâu dài nhằm cải thiện việc chọn lựa $\mathrm{BN}$ cũng như phương pháp phẫu thuật [6].

\section{TỔNG QUAN VỀ LỊCH SỬ PHẪU THUẬT FONTAN}

Nền tảng của phẫu thuật Fontan phát triển từ những năm 1940 khi người ta nhận thấy rằng áp lực $\mathrm{ĐM}$ phổi ở cá, động vật lưỡng cư, động vật có vú và chim có trị số khoảng $25 / 10 \mathrm{mmHg}$ và lực của máu TM hệ thống có thể đủ để đẩy máu về ĐM phổi [7].

Năm 1958, Glenn công bố phẫu thuật nối tận-tận đưa toàn bộ máu $\mathrm{TM}$ chủ trên vào $\mathrm{DM}$ phổi phải [15]. Phẫu thuật này ngày nay được gọi là Glenn shunt cổ điển. Tuy nhiên, vì dòng máu nuôi phổi phải chỉ đến từ TM chủ trên nên không có yếu tố gan (hepatic factor). Do vậy, sau một thời gian, các thông nối động-tĩnh mạch phổi sẽ xuất hiện làm giảm bão hoà ôxy máu [8]. Phẫu thuật này sau đó một thời gian bị rơi vào quên lãng. Tuy nhiên, khi chiến lược phẫu thuật Fontan theo hai giai đoạn khẳng định tầm quan trọng của phẫu thuật Glenn shunt trong việc giảm tỉ lệ tử vong và biến chứng, Glenn shunt lại được sử dụng nhưng có cải biên thành Glenn shunt hai hướng [2], [26].

Năm 1968, Francis Fontan và Eugene Baudet, hai phẫu thuật viên người Pháp, thực hiện thành công Phẫu thuật Fontan cho BN mắc bệnh teo van ba lá [9]. Phẫu thuật cổ điển này đầu tiên được tiến hành theo năm bước: (1) tạo Glenn shunt cổ điển vào phổi phải; (2) cắt rời thân $\mathrm{ĐM}$ phổi khỏi đường thoát thất phải; (3) nối thân ĐM phổi vào nhĩ phải qua một ống ghép đồng loại có van; (4) đặt một van đồng loại ngay chỗ nối TM chủ dưới vào nhĩ phải và (5) đóng kín vách liên nhĩ [17]. 


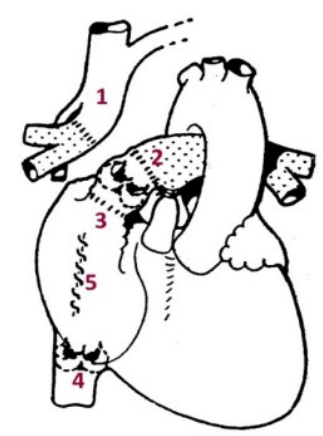

Hình 1. Phẫu thuật Fontan được mô tả trong công trình đầu tiên: (1) Glenn shunt cổ điển; (2) Cắt rời thân ĐM phổi khỏi đường thoát thất phải; (3) Nối nhĩ phải vào thân ĐM phổi qua một ống ghép đồng loại có van; (4) Nối TM chủ dưới vào nhĩ phải qua một ống ghép có van; (5) Vá kín thông liên nhĩ.

Những cải tiến ban đầu sau công bố của Fontan bao gồm việc gắn nhĩ phải vào ĐM phổi theo các phương thức khác nhau như sử dụng ống ghép có van, ống ghép đồng loại, miếng patch hoặc nối trực tiếp [13]. Trong một thập kỷ tiếp theo đó, kỹ thuật Nối trực tiếp nhĩ phải vào ĐM phổi được sử dụng rộng rãi trong điều trị teo van ba lá và sau đó mở rộng cho các biến thể tim một thất chức năng khác [17].

Ban đầu, người ta cho rằng nhĩ phải, một buồng tim có chức năng co bóp, sẽ góp phần cải thiện dòng máu từ $\mathrm{TM}$ hệ thống lên phổi. Tuy nhiên, các nghiên cứu thực nghiệm của de Leval \& $\mathrm{CS}$ đã chứng minh rằng cùng với thời gian, nhĩ phải sẽ bị giãn và mất chức năng co bóp gây nên rối loạn hướng dòng máu và đặc biệt là mất năng lượng dòng chảy [7]. Một sự kiện khác minh chứng một cách rất thuyết phục rằng toàn bộ máu $\mathrm{TM}$ hệ thống (trừ máu $\mathrm{TM}$ gan) có thể được đưa về ĐM phổi mà không cần phải qua nhĩ phải. Đây chính là trường hợp Phẫu thuật Kawashima ở những $\mathrm{BN}$ bị đứt đoạn $\mathrm{TM}$ chủ dưới kèm liên tục $\mathrm{TM}$ (bán) đơn thường gặp trong hội chứng đồng phân nhĩ trái [20].

Chính vì phát hiện đó mà các phẫu thuật viên đã bỏ hẳn phương pháp nối $\mathrm{NP}$ vào $\mathrm{ĐM}$ phổi và thay bằng Kỹ thuật nối toàn bộ $\mathbf{T M}$ chủ vào ĐM phổi (Total CavoPulmonary
Connection - TCPC). Tác giả de Leval là người đưa ra những cơ sở lý luận và thực hiện việc nối trực tiếp các $\mathrm{TM}$ chủ vào $Đ M$ phổi mà không đi qua nhĩ phải và thất phải. Tác giả sử dụng một phần mô của thành nhĩ cộng với một miếng mô không phải của nhĩ để tạo Đường hầm bên trong nhĩ (lateral tunnel) đưa máu từ $\mathrm{TM}$ chủ dưới lên ĐM phổi. Kỹ thuật mới này tạo nên dòng máu từ $\mathrm{TM}$ chủ về $\mathrm{OM}$ phổi hữu hiệu hơn, giảm nguy cơ rối loạn nhịp, huyết khối, thuyên tắc phổi và chèn ép $\mathrm{TM}$ phổi do nhĩ phải khổng lồ [5][6][17]. Ngoài ra, sự cải tiến kỹ thuật này cải thiện một cách rõ rệt dự hậu của những $\mathrm{BN}$ tim một thất chức năng do hẹp nặng hoặc teo van nhĩ thất bên trái. Với những $\mathrm{BN}$ này, đường hầm bên trong nhĩ phải cho phép máu từ $\mathrm{TM}$ phổi đổ về thất chính bên phải mà không bị cản trở bởi dòng máu từ $\mathrm{TM}$ chủ như khi sử dụng nhĩ phải làm trung gian giữa $T M$ chủ và $Đ M$ phổi [17]. Với những ưu điểm trên, cuối những năm 1980, kỹ thuật tạo đường hầm bên trong lòng nhĩ phải để dẫn máu từ $\mathrm{TM}$ chủ dưới lên ĐMP được sử dụng rộng rãi [18][28].

Một cải tiến quan trọng nữa trong phẫu thuật Fontan là việc sử dụng lại phẫu thuật Glenn shunt vốn đã bị lãng quên. Tuy nhiên, lần này, ĐM phổi không bị cắt rời khỏi thân ĐM phổi mà chỉ thực hiện nối đầu tận của 
TMC trên vào mặt bên trên của ĐM phổi phải. Phẫu thuật này được gọi là Glenn shunt cải biên hay Phấu thuật Glenn shunt hai hướng (Bidirectional Glenn Shunt Operation) hoặc còn có tên gọi khác là Nối TM chủ - ĐM phổi hai hướng (Bidirectional Cavo-Pulmonary Shunt-BCPS). Phẫu thuật này được xem như là một bước đệm trước khi phẫu thuật Fontan [2]. Lý do đằng sau việc sử dụng BCPS là giảm tải một phần cho thất, tạo điều kiện cho thất tái cấu trúc dần dần để kịp thích nghi với tình trạng thay đổi tải khi phẫu thuật Fontan. Mặc khác, mạch máu phổi cũng có thể được chuẩn bị tốt hơn. Một lý do khác nữa là sự tăng độ bão hoà ôxy máu như Glenn shunt hai hướng sẽ giúp trẻ phát triển tốt hơn cho đến khi đủ điều kiện để phẫu thuật Fontan. Trên thực tế, sử dụng Glenn shunt hai hướng theo cách tiếp cận này làm giảm tỉ lệ tử vong xuống còn $7 \%$ so với $16 \%$ nếu chỉ thực hiện phẫu thuật Fontan một giai đoạn [26]. Glenn shunt hai hướng được xem là có vai trò quan trọng trong cải thiện dự hậu ở nhóm $\mathrm{BN}$ được xếp vào nhóm Fontan có nguy cơ cao trước đây cũng như những $\mathrm{BN}$ mắc hội chứng tim trái thiểu sản [10].

Vào những năm 1980, Norwood đưa ra chiến lược Phẫu thuật Norwood theo ba giai đoạn với việc dùng thất phải làm thất hệ thống (bơm máu vào ĐM chủ) ở những trẻ em mắc hội chứng tim trái thiểu sản. Khái niệm này đã dẫn đến việc mở rộng các đối tượng được phẫu thuật theo hướng tuần hoàn Fontan [6]. Như vậy, cả thất trái lẫn thất phải đều có thể được sử dụng làm thất hệ thống.

Đầu những năm 1990, Ống ghép ngoài tim được sử dụng để nối $\mathrm{TM}$ chủ dưới vào $\mathrm{ĐM}$ phổi được giới thiệu và nhanh chóng được chấp nhận. Phẫu thuật Fontan với ống ghép ngoài tim được ưa chuộng sử dụng rộng rãi vì dễ thực hiện hơn đường hầm trong nhĩ. Một số phẫu thuật viên thậm chí còn thực hiện phẫu thuật Fontan với ống ghép màng ngoài tim mà không có hỗ trợ tuần hoàn ngoài cơ thể [17].
Năm 1990, các tác giả ở Bệnh viện Nhi Boston công bố 20 trường hợp phẫu thuật có Tạo cửa sổ thông thương giữa đường hầm bên với buồng nhĩ ở $20 \mathrm{BN}$ có nguy cơ cao như rối loạn chức năng thất, kháng lực mạch máu phổi cao. Cửa sổ thông thương này có mục đích làm giảm áp lực nhĩ phải và đảm bảo cung lượng tim trái trong giai đoạn sớm sau mổ và chấp nhận độ bão hoà ôxy máu ĐM hệ thống thấp hơn [3]. Cửa sổ này sau đó sẽ tự đóng trong một số trường hợp khi huyết động ở tuần hoàn phổi cải thiện hoặc được đóng bằng dụng cụ qua da sau khi được thông tim đánh giá kháng lực phổi. Sau khi đóng, bão hoà ôxy sẽ trở lại giá trị bình thường [16].

Gần đây sự thành công của Đặt stent ống động mạch ở trẻ sơ sinh và nhũ nhi mắc bệnh tim phụ thuộc ống, trong đó có trẻ mắc bệnh tim một thất chức năng [1] đã mở ra một hướng mới trong xử trí nhóm bệnh này, làm giảm số lần phẫu thuật. Can thiệp tim mạch cũng được ứng dụng thành công cùng với phẫu thuật trong điều trị trẻ em mắc hội chứng tim trái thiểu sản. Chiến lược hybrid kết hợp phẫu thuật và can thiệp (banding ĐM phổi, đặt stent ống ĐM và phá vách liên nhĩ bằng bóng) ít xâm lấn hơn nhưng vẫn đạt được kết quả như tiếp cận của Norwood [12].

\section{GIẢI PHẪU VÀ SINH LÝ TUẦN HOÀN FONTAN}

\subsection{Các bệnh tim một thất chức năng}

Nhóm bệnh này bao gồm (A) Nhóm teo một van nhĩ thất (thường gặp nhất là teo van ba lá, đôi khi teo van hai lá nhưng không nằm trong hội chứng tim trái thiểu sản), (B) Nhóm bệnh tim có thất chính hai đường vào (thất trái hai đường vào), (C) Nhóm tim trái thiểu sản và (D) Kênh nhĩ thất mất cân bằng (thường gặp trong hồi chứng đồng phân nhĩ phải). Các nhóm bệnh này được Gewillig sơ đồ hoá trong Hình 2 [13]. Ngoài ra, một số $\mathrm{BN}$ thực sự có hai buồng thất nhưng lại có những đặc điểm giải 
phẫu đặc thù ngăn trở việc sửa chữa theo hướng hai thất. Một ví dụ "tương đương một thất" là $\mathrm{BN}$ mắc thất phải hai đường thoát và một lỗ thông liên thất nằm rất xa khỏi van bán nguyệt. Hoặc một trường hợp khác là thất phải hai
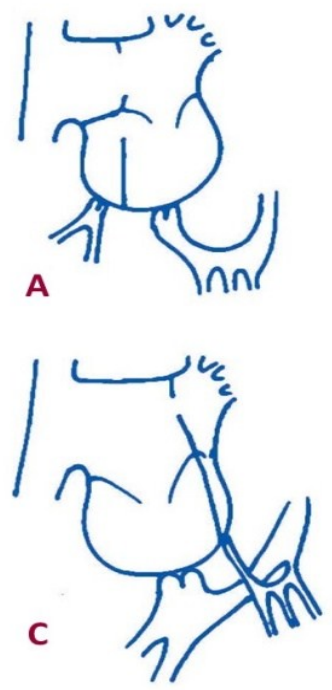

đường thoát nhưng lại có hai van nhĩ thất bắt chéo (criss-cross) nên không thể đóng thông liên thất hoặc tạo đường hầm bên trong thất do đó phải phẫu thuật theo hướng một thất, tức tuần hoàn Fontan [17].
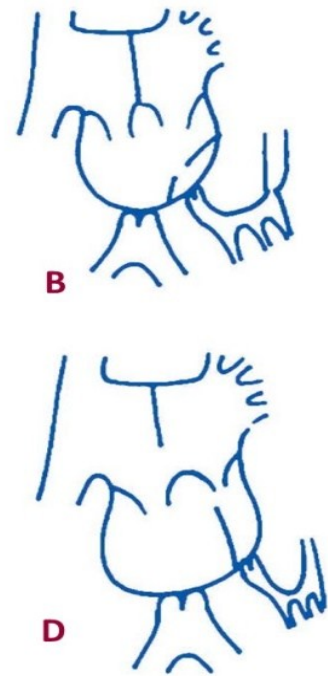

Hình 2. Sơ đồ hoá các bệnh tim bẩm sinh có thể cần phải phẫu thuật Fontan: A. Teo một van nhĩ thất; $\mathrm{B}$. Thất hai đường vào; $\mathrm{C}$. Thiểu sản một thất và $\mathrm{D}$. Kênh nhĩ thất mất cân bằng [13].

\subsection{Các thể tuần hoàn Fontan}

\subsubsection{Tuần hoàn Fontan cổ điển}

Trên những $\mathrm{BN}$ đầu tiên của chính Fontan, tác giả sử dụng Glenn shunt cổ điển, sử dụng thất phải làm buồng bơm máu $\mathrm{TM}$ chủ dưới lên ĐM phổi và có sử dụng hai van ở đường vào và đường ra của nhĩ phải [9]. Ngay sau công trình này được công bố vào năm 1971 nhiều tác giả đã cải tiến để hoàn chỉnh kỹ thuật. Kreutzer tiến hành nối trực tiếp nhĩ phải vào ĐM phổi và không sử dụng van (Hình $\mathbf{3 A}$ ) [23]. Trong một khoảng thập kỷ sau đó, đây là kỹ thuật được sử dụng rộng rãi nhất. Tuy nhiên với các biến chứng thường gặp của Fontan cổ điển như đã trình bày ở trên, kỹ thuật này không còn được sử dụng nữa [17].

\subsubsection{Tuần hoàn Fontan với đường hầm bên trong $n h \tilde{\imath}$}

Trong kỹ thuật này (Hình 3B), thay vì dùng cả nhĩ phải để dẫn máu TM chủ dưới, các nhà phẫu thuật sử dụng một phần mô nhĩ ở phía bên kết hợp với vật liệu nhân tạo bên trong nhĩ nhằm tạo nên một đường hầm bên trong nhĩ. Đường hầm này dẫn máu $\mathrm{TMC}$ dưới đi qua nhĩ lên $\mathrm{TMC}$ trên vào đổ vào $\mathrm{ĐM}$ phổi. Giữa đường hầm và nhĩ có thể chừa một lỗ thông thương (cửa sổ) hoặc không. Máu từ TM chủ trên theo Glenn shunt hai hướng đổ vào $Đ M$ phổi [4][17].

3.2.3. Tuần hoàn Fontan với ống ghép ngoài tim

Ống ghép ngoài tim là vật liệu nhân tạo (thường là ống Gore-Tex) có đường kính thay đổi được nối với đầu trên của $T M$ chủ dưới và mặt dưới của ĐM phổi phải. Như vậy, ống ghép ngoài tim hoàn toàn không đi trong nhĩ làm giảm các mũi khâu trên cơ nhĩ. Giữa ống ghép và nhĩ có thể chừa cửa sổ tương tự như trong tuần hoàn Fontan có đường hầm bên trong nhĩ. 
Tương tự như ở các thể khác, máu từ TM chủ trên cũng theo Glenn shunt hai hướng đổ vào ĐM phổi. Không ít trường hợp, $\mathrm{BN}$ có hai $\mathrm{TM}$ chủ trên. Trong trường hợp này, cả hai $\mathrm{TM}$ chủ trên đều được nối vào hai ĐM phổi một cách riêng rẽ hoặc có thể hợp lưu với nhau trước khi nối vào ĐM phổi.

Trong một số trường hợp đường đi của ống ghép không thuận lợi, ví dụ $\mathrm{TM}$ chủ dưới nằm bên trái hoặc các $\mathrm{TM}$ gan nằm xa $\mathrm{TM}$ chủ dưới, thì có thể sử dụng kỹ thuật bên trong-bên ngoài (intra-extracardiac conduit) nhằm giảm nguy cơ xoắn vặn, gập góc của ống ghép. Trong kỹ thuật này, ống ghép có một đoạn đi trong nhĩ sau đó xuyên qua thành nhĩ để ra ngoài, đi lên và nối với ĐM phổi như thông thường.
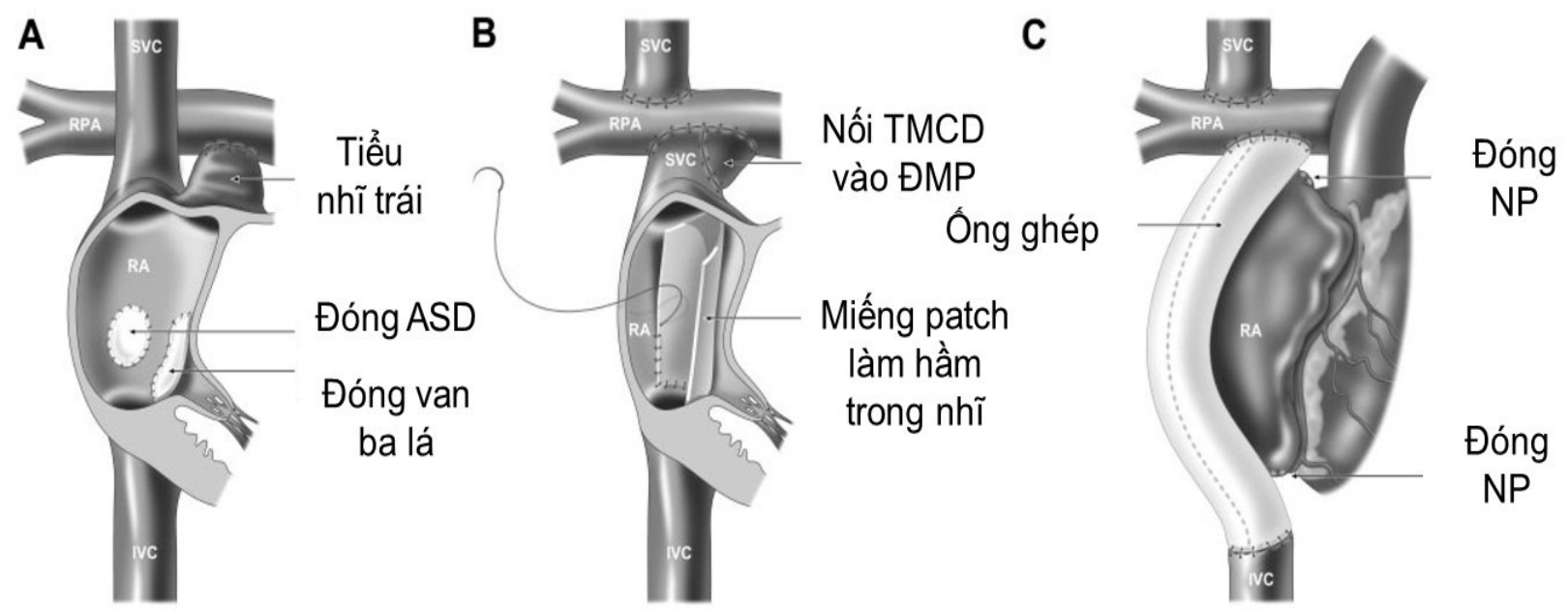

Hình 3. Các thể tuần hoàn Fontan gồm $\mathrm{A}$. Cổ điển, $\mathrm{B}$. Đường hầm bên trong nhĩ và $\mathrm{C}$. ống ghép ngoài tim. SVC: TM chủ trên; RPA: ĐM phổi phải; RA: Nhĩ phải; IVC: TM chủ dưới [4].

Cho đến nay vẫn còn nhiều ý kiến khác nhau về việc nên chọn lựa phẫu thuật Fontan có đường hầm trong nhĩ hay sử dụng ống ghép ngoài tim. Một nhóm tác giả Hàn Quốc đã so sánh dự hậu ngắn và trung hạn giữa hai nhóm bệnh này và nhận thấy cả hai nhóm đều có những kết quả khá tương đồng về tỉ lệ tử vong và bệnh tật, huyết động và sống còn trung hạn. Tuy nhiên, nhóm BN có ống ghép ngoài tim có giảm nguy cơ rối loạn chức năng nút xoang và có huyết động ngay sau mổ tốt hơn [25]. Katogi nhận thấy ưu điểm của phẫu thuật Fontan có ống ghép ngoài tim bao gồm khả năng dễ sử dụng cho mọi thể tim một thất chức năng, phẫu thuật đơn giản hơn không cần kẹp ĐM chủ và ít đường khâu trên thành nhĩ hơn. Ngược lại, những ưu điểm của phẫu thuật Fontan có đường hầm trong tim bao gồm khả năng có thể thực hiện được ở trẻ nhỏ có cân nặng thấp vì đường hầm này có một phần cơ nhĩ có thể lớn lên cùng với sự phát triển của trẻ [19]. Về mặt lý thuyết, ống ghép ngoài tim nhờ không tác động nhiều lên nhĩ sẽ làm giảm nguy cơ rối loạn nhịp. Tuy vậy, trong phân tích của mình, hai tác giả Khairy và Poirier chứng minh không có sự khác biệt giữa hai kỹ thuật. Thậm chí khi rối loạn nhịp xuất hiện, ống ghép ngoài tim sẽ gây khó khăn hơn cho kỹ thuật cắt đốt [21].

\subsection{Sinh lý tuần hoàn Fontan}

Trong tuần hoàn Fontan, tuần hoàn phổi và tuần hoàn hệ thống hoạt động không phải song song mà theo tuần tự. Dòng máu từ $\mathrm{TM}$ chủ chảy về tuần hoàn phổi theo chênh áp thuỷ 
tĩnh chứ không được bơm bởi một buồng thất nào. Động tác hít vào tạo áp lực âm trong lồng ngực đóng vai trò rất quan trọng tạo nên chênh áp này [24]. Trong tuần hoàn Fontan, các cơ chế liên quan đến kiểm soát cung lượng tim vào lúc nghỉ ngơi và lúc gắng sức hoàn toàn khác so với ở một tim bình thường. Gewillig \& $\mathrm{CS}$ đã phân tích cặn kẽ vai trò của khả năng co bóp cơ tim, tần số tim, hậu tải và cuối cùng đi đến kết luận rằng trong tuần hoàn Fontan, kháng lực mạch máu phổi đóng vai trò quan trọng nhất trong quyết định tiền tải và cung lượng tim [14]. Đảm bảo được một kháng lực mạch máu phổi thấp đòi hỏi phải tối ưu hoá nhiều yếu tố tham gia.

Năm 1977, Chousat \& CS đã đưa ra 10 tiêu chí cần phải đảm bảo để đạt được một kết quả phẫu thuật Fontan tối ưu. Mười tiêu chí này thường được gọi là Mười Điều Răn (Ten Commandments) (Bảng 1) [29].

\begin{tabular}{cl} 
Bảng 1. Muời Điều Răn để đạt đực Tuần hoàn Fontan tối uuu \\
\hline 1 & Tuổi $>4$ tuổi \\
2 & Nhịp xoang \\
3 & Hồi lưu TM hệ thống bình thường \\
4 & Thể tích nhĩ phải bình thường \\
5 & Áp lực ĐM phổi trung bình $<15 \mathrm{mmHg}$ \\
6 & Kháng lực tiểu ĐM phổi $<4$ đơn vị Wood $/ \mathrm{m}^{2}$ \\
7 & Tỉ suất ĐM phổi/ĐM chủ $>0,75$ \\
8 & Phân suất tống máu thất trái $>60 \%$ \\
9 & Van hai lá không hở \\
10 & Không có xoắn vặn ĐM phổi \\
\hline
\end{tabular}

Nhờ những tiến bộ trong phẫu thuật, gây mê hồi sức, sự phát triển các thuốc điều trị mới và đặc biệt là vai trò của can thiệp tim mạch nhi mà Mười Điều Răn ở trên có thể không còn luôn luôn bắt buộc. Tuy vậy, để đảm bảo được một tuần hoàn Fontan tối ưu, kéo dài tuổi thọ, chất lượng sống, giảm thiểu các biến chứng thì cần hải đặc biệt quan tâm đến Năm Điều Răn còn lại như sau [17]: biến dạng

1. Hệ ĐM phổi không được xoắn vặn,

2. Kháng lực mạch máu phổi thấp

3. Áp lực cuối kỳ tâm trương thất phải thấp

4. Không có cản trở dòng máu hệ thống
5. Đảm bảo được chức năng của van nhĩ thất của buồng thất hệ thống.

Một lần nữa, để đạt được Mười hay Năm Điều Răn, thì ngay lập tức sau sinh, chiến lược xử trí tiền Fontan phải làm sao để đạt được những tiêu chí này [13].

\section{CHIẾN LƯợC TIẾP CẬN BỆNH TIM MỘT THẤT CHỨC NĂNG}

Trước đây, phẫu thuật Fontan được thực hiện một thì [9]. Sau đó, phẫu thuật Fontan hai thì với việc sử dụng phẫu thuật Glenn shunt hai hướng được sử dụng thường quy nhằm giảm tỉ lệ tử vong và biến chứng [13][17] [22]. Tuy nhiên, với một trẻ sinh ra có lưu lượng máu lên 
phổi hạn chế (gây thiếu ôxy) hoặc quá mức (suy tim và nguy cơ tăng áp phổi) thì trước khi phẫu thuật Glenn shunt hai hướng, chúng ta cần phải tiến hành một bước phẫu thuật hoặc can thiệp nhằm tăng hoặc hạn chế lượng máu lên phổi một cách tương ứng.

\subsection{Chiến luộc phẫu thuật}

Chúng tôi trình bày ngắn gọn chiến lược xử trí BN tim một thất chức năng theo ba giai đoạn.

\subsubsection{Giai đoạn 1}

Ngay sau khi ra đời, do kháng lực mạch máu phổi còn cao cũng như kích thước các mạch máu phổi còn hạn chế, phẫu thuật Glenn shunt không thể thực hiện được. Để đảm bảo lượng máu cho tuần hoàn phổi trong trường hợp máu lên phổi hạn chế, trước đây người ta thường tiến hành phẫu thuật tạo shunt BlalockTaussig cải tiến với ống nối nhân tạo đường kính $4 \mathrm{~mm}$ hoặc $3,5 \mathrm{~mm}$ [17]. Phẫu thuật này có thể tiến hành ngay sau sinh. Ngày nay, phẫu thuật tạo shunt Blalock-Taussig cải tiến thường được thay thế bằng đặt stent ống ĐM [1].

Ngược lại, một số trẻ sơ sinh có tim một thất chức năng nhưng không có hẹp phổi sẽ có lượng máu lên phổi tăng có nguy cơ gây suy tim và tăng áp phổi không thuận lợi cho phẫu thuật Fontan về sau. Chính vì vậy những trẻ này cần được phẫu thuật đặt vòng thu nhỏ ĐM phổi (banding ĐM phổi) nhằm hạn chế lượng máu lên tuần hoàn phổi [17].

Hiện nay, một số trẻ em mắc hội chứng tim trái thiểu sản, người ta có thể thay thế phẫu thuật Norwood I bằng thủ thuật hybrid kết hợp phẫu thuật banding ĐM phổi với đặt stent ống ĐM kèm phá vách liên nhĩ bằng bóng qua da [12].

\subsubsection{Giai doạn 2}

Thường được tiến hành khi trẻ được 6 tháng tuổi. Phẫu thuật được thực hiện là nối $\mathrm{TM}$ chủ trên vào ĐM phổi (BCPS) hay còn gọi là Glenn shunt hai hướng [17]. Trong trường hợp có hai $\mathrm{TM}$ chủ trên, một số tác giả cố gắng đưa hai dòng máu này về càng gần nhau trên vị trí nối vào ĐM phổi càng tốt. Một số trẻ tim một thất chức năng có lưu lượng máu lên phổi không quá cao hoặc không quá thấp (thường là trong trường hợp tim một thất có hẹp phổi không quá nặng) thì không cần phải trải qua bước 1 mà có thể chờ thực hiện phẫu thuật bước 2 .

\subsubsection{Giai đoạn 3}

Phẫu thuật Fontan thường được tiến hành từ khoảng 36 tháng tuổi. Có thể phẫu thuật tạo đường hầm trong nhĩ hoặc sử dụng ống ghép ngoài tim (Hình 4) có hoặc không có chừa cửa sổ.

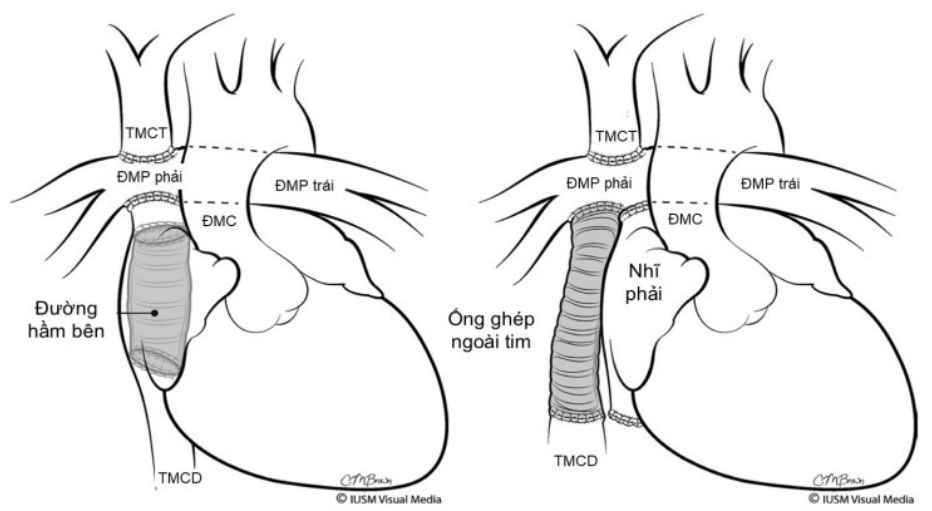

Hình 4. Phẫu thuật Fontan có đường hầm trong nhĩ (A) và sử dụng ống ghép ngoài tim (B). ĐMC: động mạch chủ; ĐMP: động mạch phổi; TMCT: tĩnh mạch chủ trên; TMCD: tĩnh mạch chủ dưới. (Nguồn: Fredenburg et al. [11]) 


\subsection{Nội khoa và can thiệp}

Can thiệp có thể có vai trò trong giai đoạn sớm nhằm thay thế phẫu thuật Blalock-Taussig bằng thủ thuật đặt stent ống ĐM [1] hoặc có thể phối hợp với phẫu thuật nhằm thay thế phẫu thuật Norwood I [12]. Can thiệp đặt stent ĐMC giải quyết hẹp eo hoặc đặt stent ĐMP để điều trị hẹp ĐMP, đặt stent ống ghép đã được ứng dụng thành công làm giảm chênh áp mà không cần phải phẫu thuật lại [8][29].

Can thiệp đóng bít tắc ĐM bàng hệ chủ phổi trước và sau phẫu thuật Fontan, can thiệp đóng tuần hoàn tĩnh mạch-tĩnh mạch, đóng thông nối động-tĩnh mạch phổi, đóng cửa sổ đường hầm-nhĩ hoặc ống ghép-nhĩ cũng là những phương pháp điều trị được sử dụng rộng rãi trên thế giới [8][17][29] cũng như tại Bệnh viện Đại học Y Dược thành phố Hồ Chí Minh.

Với sự phát triển của siêu âm tim $3 \mathrm{D}$ và cộng hưởng từ tim mạch, thầy thuốc tim mạch đã có trong tay những kỹ thuật hình ảnh ưu việt hơn giúp cho phẫu thuật viên một cái nhìn toàn diện và sâu sắc hơn về giải phẫu van nhĩ thất cũng như van bán nguyệt và dĩ nhiên đánh giá tốt hơn bệnh lý nguyên nhân của hở van bởi cơ chế hở van ở mỗi bệnh nhân là khác nhau. Các kỹ thuật hình ảnh tiên tiến này cho phép phẫu thuật viên đưa ra được kế hoạch và kỹ thuật phẫu thuật để loại bỏ hoàn toàn hoặc giảm thiểu bất thường ở các lá van [29].

Những bất thường về nhịp tim và tần số bao gồm rối loạn nhịp nhĩ do vòng vào lại, loạn nhịp chậm và khả năng mất đáp ứng hướng thì rất thường gặp ở BN sau phẫu thuật Fontan [4][21]. Liệu pháp tái đồng bộ sử dụng tạo nhịp đa ổ đã chứng tỏ hiệu quả ở những $\mathrm{BN}$ tim một thất chức năng có thời gian $\mathrm{QRS}$ kéo dài và mất đồng bộ co cơ thất [29].

Một số kỹ thuật mới được ứng dụng hứa hẹn nhiều tiềm năng ứng dụng trong lâm sàng bao gồm Doppler mô, hình ảnh đồng bộ mô, siêu âm tim 3D, kỹ thuật truy điểm (speckle tracking), strain. Nhờ tiên đoán được những vấn đề có thể xuất hiện nhờ vào thái độ thực hành tích cực đón đầu trước khi những biến chứng thực sự xảy ra trong phẫu thuật Fontan, chúng ta có thể phát hiện được những bất thường sớm hàng tháng hoặc hàng năm so với trước đây. Nhờ vậy, bệnh nhân sẽ tránh được những đáp ứng bất lợi như hoạt hoá thần kinh thể dịch, chết tế bào lập trình và suy biến sức khoẻ tim mạch, đôi khi khó phục hồi [29].

\section{BIẾN CHÚNG CỦA TUẦ HOÀN FONTAN}

Cùng với sự cải thiện về chăm sóc chu phẫu, thực hiện phẫu thuật Fontan theo hai giai đoạn (Glenn shunt và Fontan) và phẫu thuật Fontan ở lứa tuổi nhỏ, tỉ lệ tử vong liên quan đến cuộc mổ giảm xuống còn khoảng 5\% (so với 15 đến $30 \%$ như trước đây) và tỉ lệ sống 20 năm sau Fontan hiện tại là 85\% [8]. Tuy nhiên, nhóm BN được phẫu thuật Fontan luôn phải đối mặt với hai nguy cơ: tuần hoàn Fontan diễn tiến xấu (failing Fontan) và suy tuần hoàn Fontan thực sự (failed Fontan).

\subsection{Tuần hoàn Fontan diễn tiến xấu}

\subsection{Chậm tăng truởng thể chất}

Nhìn chung, $\mathrm{BN}$ Fontan thường thấp hơn quần thể bình thường. Tuy nhiên, ngày càng có nhiều bằng chứng cho thấy chậm tăng cân một cách không giải thích được có thể là một chỉ dấu sớm của cung lượng tim không đạt được mức bình thường. Trước một trẻ đã được phẫu thuật Fontan có chậm tăng trưởng, cần phải tiến hành khảo sát huyết động một cách tỉ mỉ để làm sao tối ưu hoá huyết động bằng biện pháp can thiệp hoặc phẫu thuật để điều trị những tắc nghẽn tồn lưu hoặc bất thường về van tim [8]. 


\subsubsection{Tím}

Bệnh nhân Fontan thường có tím mức độ rất nhẹ do máu từ xoang vành được đổ về tuần hoàn hệ thống. Tuy nhiên, bão hoà thấp $<90 \%$ là một gợi ý của một luồng shunt phải sang trái (trong tim hoặc do thông nối TM-TM) hoặc do thông nối động-tĩnh mạch phổi. Với những bất thường như vậy, thông tim có thể phát hiện được và có thể can thiệp để bít tắc những thông nối một cách có hiệu quả. Những $\mathrm{BN}$ được phẫu thuật Glenn shunt cổ điển xuất hiện thông nối động $\mathrm{TM}$ trong phổi phải do thiếu yếu tố gan cần phải được phẫu thuật để tái lập thông thương của $Đ M$ phổi phải với phần còn lại của hệ $\mathrm{DM}$ phổi. Trường hợp những $\mathrm{BN}$ được phẫu thuật Fontan cổ điển thường có tuần hoàn bàng hệ "giải áp" hoặc shunt ở tầng nhĩ. Phẫu thuật cắt rời $\mathrm{TM}$ chủ khỏi nhĩ phải, nối trực tiếp $\mathrm{TM}$ chủ vào ĐM phổi và thu nhỏ nhĩ (Fontan conversion) kèm hoặc không kèm phẫu thuật maze điều trị loạn nhịp có thể sẽ giải áp và làm giảm tuần hoàn bàng hệ TM [27].

\subsubsection{Cản trở đưòng lưu thông của máu} và rối loạn chức năng van tim

Sự xuất hiện của các bất thường về huyết động thường rất thầm lặng ở $\mathrm{BN}$ Fontan và thường được chẩn đoán muộn cho đến khi rất nặng. Giảm khả năng gắng sức, giảm bão hoà ôxy máu khi nghỉ ngơi hoặc gắng sức, hiện diện âm thổi ở tim, gan to, bóng tim lớn là những chỉ dấu của bất thường về mặt huyết động. Trong tuần hoàn Fontan, một chênh áp $1 \mathrm{mmHg}$ cũng đã có ý nghĩa huyết động. Hẹp hoặc hở van nhĩ thất sẽ làm tăng áp nhĩ và do vậy cản trở dòng chảy trong phổi. Tắc nghẽn ở ĐM chủ sẽ làm tăng công thất đưa đến dày thất và giảm chức năng tâm trương gây ảnh hưởng đến dòng máu từ phổi về [8].

\subsubsection{Rối loạn nhịp}

Rối loạn nhịp bao gồm rối loạn chức năng nút xoang (gặp đến $40 \%$ ở BN được phẫu thuật nối nhĩ phải vào ĐM phổi), nhịp bộ nối, block nhĩ thất, rối loạn nhịp trên thất và thất làm tăng nguy cơ đột tử do rối loạn nhịp. Loạn nhịp nhanh sẽ rất nhanh chóng đưa đến rối loạn huyết động ở BN Fontan chính vì vậy cần được điều trị một cách tích cực. Điều trị cắt đốt bằng sóng cao tần ở BN Fontan đòi hỏi cao về mặt kỹ thuật tuy nhiên tî̉ lệ thành công thấp [21]. Với những $\mathrm{BN}$ được nối trực tiếp nhĩ phải vào ĐM phổi, việc phẫu thuật lại tạo ống ghép ngoài tim kèm với phẫu thuật maze được tiến hành từ năm 1994 và đạt được những kết quả rất khích lệ [8].

\subsubsection{Báng}

Báng bụng có thể là hậu quả của tăng áp nhĩ phải, bệnh ruột mất protein hoặc rối loạn chức năng gan và đồi hỏi cần phải được khảo sát rất kỹ để xác định được nguyên nhân mới có thể đưa ra biện pháp điều trị thích hợp. Báng là một cảnh báo của một tình trạng suy tuần hoàn Fontan thực sự đang đến gần.

\subsubsection{Rối loạn đông máu}

Huyết khối thường có khuynh xuất hiện ở những $\mathrm{BN}$ có cung lượng tim thấp, đặc biệt những $\mathrm{BN}$ có giãn nhĩ phải, ứ trệ dòng máu. Bệnh nhân Fontan cũng có nguy cơ cao xuất hiện những bất thường yếu tố đông máu như trong bất cứ trường hợp ứ trệ máu ở gan khác: thiếu hụt protein $\mathrm{S}$, protein $\mathrm{C}$ và antithrombin III. Nhiễm trùng hoặc mất nước cũng có thể làm tăng nguy cơ xuất hiện huyết khối. Huyết khối trong TM hệ thống có thể gây thuyên tắc ĐM phổi. Thuyên tắc ồ ạt có thể gây nên sốc, rối loạn nhịp và tử vong. Đây là nguyên nhân gây tử vong ngoài bệnh viện thường gặp nhất ở $\mathrm{BN}$ Fontan. Vi huyết khối trên diện rộng và tái diễn có thể dẫn đến bệnh mạch máu phổi tắc nghẽn, một biến chứng muộn nhưng có khả năng gây tử vong ở BN tuần hoàn Fontan [13]. 


\subsubsection{Thai kỳ}

Hầu hết phụ nữ sau phẫu thuật Fontan đều có chu kỳ kinh nguyệt bình thường do vậy những đối tượng này vẫn có khả năng thụ thai. Thai kỳ và chuyển dạ làm tăng tải rõ rệt lên hệ tim mạch. Thai kỳ bình thường làm tăng cung lượng lên khoảng 30-40\% vào thời điểm 24 tuần thai và làm tăng thể tích máu lên khoảng 30-40\% nhưng làm giảm kháng lực ngoại biên. Thai phụ thường có biểu hiện ứ dịch và có tình trạng tăng đông. Điều này làm tăng nguy cơ huyết khối $\mathrm{TM}$ và thuyên tắc phổi. Tuy nhiên, đã có những $\mathrm{BN}$ Fontan có thai và sinh nở thành công. Những phụ nữ có huyết động tốt sau phẫu thuật thường có thể dung nạp tốt thai kỳ và chuyển dạ [30]. Như vậy, nếu một phụ nữ đã được phẫu thuật Fontan có huyết động cũng như lâm sàng tốt và rất mong muốn có con thì dường như không có lý do để chống chỉ định. Tuy nhiên, $\mathrm{BN}$ và chồng cùng gia đình phải ý thức được rằng nguy cơ cho chính mẹ và con đều tăng [13].

\subsection{Suy tuần hoàn Fontan thục sụ}

Suy tuần hoàn Fontan thực sự có thể xem là một thảm hoạ vì $\mathrm{BN}$ suy tim xung huyết với biểu hiện phù toàn, giảm cung lượng tim gây hạn chế rất nặng khả năng gắng sức, những cơn nhịp nhanh tái diễn, bệnh ruột mất protein hoặc viêm phế quản khạc chất dẻo (plastic bronchitis) [13]. Một số trường hợp hiếm, suy tuần hoàn Fontan thực sự xuất hiện sớm sau mổ và biện pháp điều trị duy nhất là cắt bỏ tuần hoàn Fontan. Suy tuần hoàn Fontan xuất hiện muộn bao gồm những bất thường về huyết động và tổn thương nhiều cơ quan. Trường hợp này thường đề kháng điều trị nội khoa, can thiệp và phẫu thuật. Điều trị chỉ mang tính giảm nhẹ triệu chứng và chờ đợi ghép tim [8]. Biểu hiện của suy tuần hoàn Fontan được tóm tắt trong Bảng 2.

\section{Bảng 2. Nhũ̃ng biểu hiện của suy tuần hoàn Fontan thục sụ}

\section{Cơ quan}

Suy Fontan sớm

Bệnh ruột mất protein

Viêm phế quản khạc chất dẻo

Rối loạn chức năng thất tiên phát

Tăng kháng lực phổi tiến triển Suy gan thận

Suy thận
Tần suất

$3 \%$

$2-13 \%$

$<2 \%$

$7-10 \%$

Không rõ

\section{Biểu hiện}

Cung lượng tim thấp, tràn dịch màng phổi, tràn dưỡng trấp màng phổi, bụng báng, gan lớn.

Báng bụng, phù ngoại biên, tràn dịch màng phổi, tiêu chảy, kém hấp thu mỡ, giảm albumin máu.

Thở nhanh, ho, khò khè, khạc ra chất dẻo hình dạng cây phế quản.

Khả năng gắng sức giảm dần, hở van nhĩ thất, gan lớn, báng.

Giảm bão hoà ôxy máu
Cho đến hiện tại, sau nửa thế kỷ tồn tại của tuần hoàn Fontan, chúng ta vẫn chưa có những biện pháp điều trị một cách triệt để những trường hợp suy tuần hoàn Fontan. Hiện nay chúng ta chỉ mới bắt đầu có được những dữ kiện từ các thử nghiệm lâm sàng ngẫu nhiên có đối chứng liên quan đến tối ưu hoá xử trí nội khoa ở BN Fontan. Xử trí bệnh nhân Fontan còn tuỳ thuộc vào quan điểm của từng thầy thuốc, từng trung tâm và thường dựa trên 
những báo cáo không hệ thống hoặc những thử nghiệm lâm sàng chưa có đủ độ mạnh cần thiết. Liệu chúng ta có thể ngoại suy từ phác đồ điều trị suy tim ở người lớn có hai buồng thất chức năng cho những $\mathrm{BN}$ Fontan hay không? Các thuốc ức chế phosphodiesterase-5 như sildenafil ngoài việc làm giãn mạch có có tác dụng tăng co bóp cơ tim hay không? Và đâu là cách tiếp cận thận trọng và hiệu quả nhất trong việc giữ cho nhóm $\mathrm{BN}$ này không bị ảnh hưởng của huyết khối, thuyên tắc mạch? Chỉ bằng cách thực hiện những công trình nghiên cứu ngẫu nhiên với số lượng bệnh nhân lớn ở các trung tâm có kinh nghiệm mới có thể đưa ra những câu trả lời chắc chắn được. Đó là thách thức nhưng đồng thời cũng là cơ hội của các thầy thuốc trong lĩnh vực tim bẩm sinh và phẫu thuật tim bẩm sinh vào thời điểm nửa thế kỷ sau khi Fontan thực hiện cuộc cách mạng trong điều trị bệnh tim một thất chức năng.

\section{KẾT LUẬN}

Những kiến thức sâu rộng về sinh lý tuần hoàn tim một thất và tuần hoàn Fontan đã đưa đến những phẫu thuật có tính cách mạng cùng những cải tiến hợp lý trong phẫu thuật và can thiệp ở trẻ em mắc bệnh tim một thất. Điều này đã cải thiện rõ khả năng sống còn, nâng cao chất lượng sống của $\mathrm{BN}$, giảm thiểu những biến chứng. Tuy nhiên những yếu tố huyết động không thuận lợi, các yếu tố nguy cơ sẵn có hoặc tồn lưu vẫn tiếp tục làm tăng những biến chứng ở BN Fontan. Để đảm bảo được những tiêu chí cho một tuần hoàn Fontan tối ưu, ngay khi trẻ sinh ra đời, chiến lược xử trí phải nhắm đến đích đảm bảo một kháng lực mạch máu phổi thấp nhất, giải phẫu mạch máu phổi tốt nhất, chức năng các van nhĩ thất bình thường, áp lực thất hệ thống cuối kỳ tâm trương thấp và đường ra của ĐM hệ thống không bị tắc nghẽn. Luôn ý thức rằng những biến chứng sau phẫu thuật
Fontan có thể xảy ra vào bất cứ thời điểm nào và ở bất kỳ $\mathrm{BN}$ nào là một thái độ thực hành đúng đắn. Một khi có nghi ngờ bất thường thì việc thăm khám lâm sàng, các test gắng sức, chẩn đoán hình ảnh, thông tim can thiệp cần phải được chỉ định chặt chẽ và kết quả phải được phân tích một cách tỉ mỉ. Xử trí những trường hợp tuần hoàn Fontan có diễn tiến xấu đòi hỏi phải có sự phối hợp liên chuyên khoa. Tuy nhiên, trong một số trường hợp, biện pháp điều trị duy nhất cho suy tuần hoàn Fontan chỉ là ghép tim. Hiện nay, các nghiên cứu vẫn đang được tiếp tục đẩy mạnh nhằm tìm hiểu sâu hơn nữa các cơ chế gây suy tuần hoàn Fontan đồng thời đưa ra những biện pháp xử trí phù hợp và hiệu quả hơn.

\section{TÀI LIỆU THAM KHẢO}

1. Alwi M, Choo KK, Latiff HA, Kandavello G, Samion H, Mulyadi D. Initial results and medium-term follow-up of stent implantation of patent ductus arteriosus in ductdependent pulmonary circulation. JACC. 2004; 40: 438-445.

2. Bridges N, Jonas RA, Mayer JE, et al. Bidirectional cavopulmonary anastomosis as interim palliation for high-risk Fontan candidates: early results. Circulation. 1990; 82: IV170-IV176.

3. Bridges ND, Lock JE, Castaneda AR. Baffle fenestration with subsequent transcatheter closure; modification of the Fontan operation for patients at increased risk. Circulation.1990; 82:1681-1689.

4. d'Udekem Y, Iyengar AJ, Cochrane AD, Grigg LE, Ramsay JM, Wheaton GR, Penny DJ, Brizard CP. The Fontan procedure: Contemporary techniques have improved long-term outcomes. Circulation. 2007; 116: S157-S164. 
5. De Leval MR, Kilner P, Gewillig M, Bull C. Total cavopulmonary connection: a logical alternative to atriopulmonary connection for complex Fontan operations: experimental studies and early clinical experience. J Thorac Cardiovasc Surg. 1988; 96: 682-695.

6. De Leval, M. R. \& Deanfield, J. E. Four decades of Fontan palliation. Nat. Rev. Cardiol. 2010; 7: 520-527.

7. De Leval, M.R. The Fontan Circulation: A Challenge to William Harvey. Nat Clin Pract Cardiovasc Med. 2005; 2: 202-208.

8. Deal BJ, Jacobs ML. Management of the failing Fontan circulation. Heart. 2012; 98:1098-1104.

9. Fontan, F. \& Baudet, E. Surgical repair of tricuspid atresia. Thorax. 1971; 26: $240-48$.

10. Forbess JM, Cook N, Serraf A, et al. An institutional experience with second- and third-stage palliative procedures for hypoplastic left heart syndrome: the impact of the bidirectional cavopulmonary shunt. J Am Coll Cardiol. 1997; 29: 665-670.

11. Fredenburg TB, Johnson TR, Cohen MD. The Fontan procedure: anatomy, complications, and manifestations of failure. Radiographics. 2011; 31: 453-63.

12. Galantowicz M, Cheatham JP, Phillips A, Cua CL, Hoffman TM, Hill SL, Rodeman R. Hybrid approach for hypoplastic left heart syndrome: Intermediate results after the learning curve. Ann Thorac Surg. 2008; 85: 2063-71.

13. Gewillig M. The Fontan circulation. Heart. 2005; 91: 839-846.

14. Gewillig M, Brownb SC, Eyskensa B, Heyinga R, Ganamea J, Budtsa W, La Gerchea
A, Gorenfloa M. The Fontan circulation: who controls cardiac output? Interactive CardioVascular and Thoracic Surgery. 2010; 10: 428-433.

15. Glenn WWL. Circulatory bypass of the right side of the heart - Shunt between superior vena cava and distal right pulmonary artery - Report of clinical application. N Engl J Med. 1958; 259:117-12.

16. Goff DA, Blume ED, Bauvreau K, et al. Clincial outcome of fenestrated Fontan patients after closure. Circulation. 2000;102: 2094-2099.

17. Hancock Friesen C.L., Forbess J.M. Surgical management of the single ventricle. Progress in Pediatric Cardiology. 2002; 16: 47-68.

18. Jonas RA, Castaneda AR. Modified Fontan procedure: Atrial baffle and systemic to pulmonary artery anastomotic techniques. J Card Surg. 1988; 3: 91-96.

19. Katogi T. Extracardiac conduit Fontan procedure versus intra-atrial lateral tunnel Fontan procedure. General Thoracic and Cardiovascular Surgery. 2012; 60: 792-795.

20. Kawashima Y, Kitamura S, Matsuda $\mathrm{H}$, et al. Total cavopulmonary shunt operation in complex cardiac anomalies. A new operation. J Thorac Cardiovasc Surg. 1984; 87: 74-81.

21. Khairy P, Poirier N. The extracardiac conduit is not the preferred Fontan approach for patients uith univentricular hearts. Circulation. 2012; 126: 2516-2525.

22. Khairy P, Poirier N, Mercier LA. Univentricular Heart. Circulation. 2007; 115: 800-812.

23. Kreutzer G, Galindez E, Bono H, 
dePalma C, Laura JP. An operation for the Fontan circulation: mid-term results. Interactive correction of tricuspid atresia. J Thorac CardioVascular and Thoracic Surgery. 2016; Cardiovasc Surg. 1973; 66: 613-621. 23:14-17

24. Le Minh Khoi, Nguyen Hoang Dinh, 28. Puga FJ, Chiavarelli M, Hagler DJ. $\mathrm{Vu}$ Tri Thanh, Truong Quang Binh. Modification of the Fontan operation applicable Cardiopulmonary interaction in patients with heart disease. Journal of Clinical Medicine. 2017; 42: 19-23.

25. Lee JR, Kwak JG, Kim KC, Min SK, Kim WH, Kim YJ, Rho JR. Comparison of lateral tunnel and extracardiac conduit Fontan procedure. Interactive CardioVascular and Thoracic Surgery. 2007; 6: 328-330.

26. Norwood WI, Jacobs ML. Fontan's procedure in two stages. Am J Surg. 1993; 166: 548-551.

27. Park HK, Shin HJ, Park YH. to the patients with left atrioventricular valve atresia or single atrioventricular valve. Circulation. 1987; 76: III53-III60.

29. Stern HJ. Fontan "Ten Commandments" revisited and revised. Pediatr Cardiol. 2010; 31: 1131-1134.

30. Therrien J, Warnes C, Daliento L, et al. Canadian Cardiovascular Society Consensus Conference 2001 update: recommendations for the management of adults with congenital heart disease part III. Outcomes of Fontan conversion for failing 